\title{
Consumers' purchase behavior in Bangladesh: green products perspectives
}

\section{Burhan Uddin}

MBA Student, Department of Marketing, Comilla University, Comilla-3506, Bangladesh.

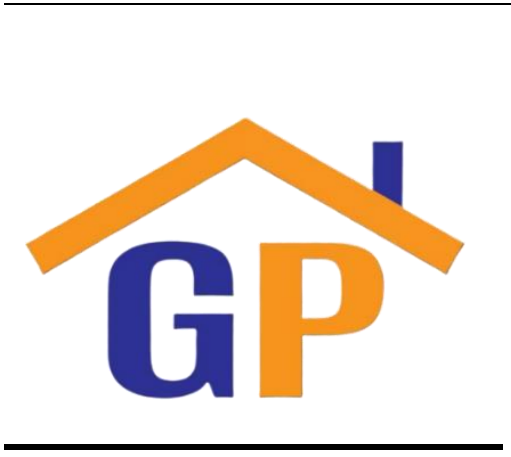

Article History

Received on 27 February 2021

Revised on 4 March 2021

Accepted on 5 March 2021

\begin{abstract}
Purpose: This study aimed to identify the influential aspects of consumers' purchase behavior of green products perspectives in Bangladesh.
\end{abstract}

Research methodology: The nature of research was descriptive. The study was used convenience and judgmental sampling. Primary and secondary data both were used. Primary data were gained through a structured questionnaire by online survey from 324 Bangladeshi consumers using a seven-point Likert scale. Data were analyzed by SPSS 25.0 version.

Results: All aspects except perceived quality, and environmental consciousness had a positive and significant effect on consumers purchase behavior toward green products in Bangladesh.

Limitations: The study was conducted \& focused on Bangladeshi consumers in the contexts of green products only.

Contribution: The results of the study will be supportive for the scholars, government, marketing specialist, and business people to attain an insight into consumers' green buying behavior in Bangladesh and direct them to discover other significant factors related to consumers' green purchase behavior so that they can formulate their strategies \& policies regarding environmental and consumption issues.

Keywords: Green products, consumers purchase behavior, green marketing, influential aspects.

How to cite: Uddin, B. (2021). Consumers' purchase behavior in Bangladesh: green products perspectives. Journal of Sustainable Tourism and Entrepreneurship, 1(4), 305-318.

\section{Introduction}

Green products are sustainable and environmentally friendly products intended to limit their environmental effects throughout their entire life-cycle. Green products are commonly recognized by using having two fundamental dreams - decreasing waste and maximizing useful resource efficiency. They have manufactured the use of toxic-free substances and environmentally-friendly strategies and are licensed through diagnosed corporations like Energy star, Forest Stewardship Council, etc. Environmental degradation and sustainability are regarded to be amongst the most serious troubles we face in today's world, and there is a developing awareness concerning all things related to the environment. A current learn about exhibits that men and women rank environmental issues as today's pinnacle challenge, accompanied by the economy, healthcare, unemployment, and crime (Paetz et al., 2012). Environmental difficulties are so vital that numerous administrative groups worldwide had been searching to put together imperative legal guidelines and guidelines to shield the atmosphere. Meanwhile, customers are paying extra interest to buy eco-friendly products and supplies. They are greater and extra inclined to buy environmentally friendly or so-called green products, even although these merchandises are frequently pricier (Sua et al., 2012). 
Green advertising and marketing turn into a foremost fashion in today's enterprise world however, this style is nonetheless new in Asian nations (Wahid et al., 2011). Nowadays, Asian nations grow to be the foremost target market by means of worldwide entrepreneurs due to the enlargement of environmental attention and the buying electricity of Asian buyers (Noor \& Muhammad, 2012). Besides that, buyers' conduct and exercise as properly as the enterprise in manufacturing and market have also been modified due to the growing recognition of environmental problems (Barber et al., 2012). However, the nearby and worldwide entrepreneurs are dealing with difficulties in creating ample and advantageous advertising and marketing techniques triggered by means of missing statistics associated with the customers' green buy purpose in that specific nation (Aman et al., 2012).

For several years, Bangladesh has experienced a digital revolution. The country's economic system developing at $7 \%$, and quickly it will be turned into a middle-income country. However, historical industries like readymade garments \& fisheries grow, and new industries such as ICT appear. A considerable challenge remains: how do Bangladesh's stable excessive monetary and technological boom with environmental sustainability? As a developing country, Bangladesh has to adapt when it derives to green innovation. Bangladesh does no longer has to create revolutionary green technology; instead put in force in existing sectors. It is pretty tough to trade current applies, specifically in Bangladesh's extraordinarily administrative putting; however, it is not always impossible. The first initiative closer to green innovation requires to come from the government itself. While the government has been profitable in pushing green technological know-how in several sectors, such as banking, they have not definitely appeared in many different necessary sectors, such as building and architecture. The green constructions in Dhaka are all non-public schemes. To undertake green technology, a country wants to be extra open to worldwide exchange and foreign direct investment (FDI). Higher tariffs on renewable electricity technologies, paired with fossil fuel grants, solely preclude the increase of green innovation globally. Now, the Bangladeshi authorities use feed-in-tariffs to speed up the renewable power zone (Daily Star). The population of Bangladesh is estimated at over 18 million in 2020. One of the largest challenges for Bangladesh in the coming years is to deal with this overpopulation by using retaining meals safety and the environment. With scarce sources like a land meeting, the meals demand of this overpopulation is difficult. To meet the demand, farmers use chemical fertilizers and pesticides that are ruining our surroundings from days to days. Also, product or commodities used for daily existence residing is no longer eco-friendly or disposable. By realizing this scenario, demand for ecofriendly merchandise or green products is rising. Currently, few green products are accessible in the Bangladeshi market.

The study's core objective is to investigate the factors that have positive and significant influences on the customers' purchase behavior towards green products. Other objectives include: to find out the impact of environmental responsibility, green advertising, environmental consciousness, environmental protection, perceived quality, social appeal, and environmental knowledge on customer's purchase intention towards green products. To evaluate the socio-demographic characteristics of respondents and evaluating the green product's scenario in Bangladesh.

\section{Literature Review}

\subsection{Green Purchase Behavior (PB)}

Green buying can be described as the buy or shopping for merchandise that can decrease the environmental effect. A green product is compatible with eco-friendly products (Kawitkar, 2013), environmental-friendly products, and ecological products (Chen \& Chai, 2010). Chen and Chai (2010) explained that green products are the products that have minimal have an effect on the surroundings, and it comprises techniques with recycled materials, decreased packaging, and the usage of much fewer damaging substances. Aligned with the definitions above, Lee (2008) described green buying as the buying of procurement efforts that supply preferences to merchandise or offerings which are least damaging to the environmental and human health. Besides, Rashid (2009) conceptualized green buy behavior as the likelihood and readiness of an individual to offer the want to green merchandise over traditional products in their buy considerations. Chan (2001) described green buying as a distinct sort of eco-friendly conduct that customers function to categorical their subject to the environment. Values influence green buy selection, attitudes, information, need, stimulus, and beliefs. Two components are 
observed to be necessary for the buy choice. One is the inner that encompass environmental responsibility, eco-friendly behavior, green involvement, and environmental knowledge. Likewise, exterior elements contain social popularity and merchandise elements like material, performance, exceptional, and fee of merchandise (Vermeir \& Verbeke, 2004). Past studies defined that green buy choice capability to guide green companies, tackle environmental problems to purchase green merchandise, and social conformity (Albayrak et al., 2013).

\subsection{Perceived Quality $(P Q)$}

Perceived quality refers to customer appreciation of the exceptional of a product (Tsiotsou, 2006); represents consumers' general decision on the dominance of a product (Zeithaml, 1988). The research analyzed the perceived satisfaction by using the 4 dimensions of Petrick (2002): dependability, reliability, superiority, and consistency, considering these can be used to measure consumers' ordinary judgment of a product or service. In the context of consumers' satisfaction, Chaudhuri (2002) viewed perceived quality to be an influential factor, in that the greater perceived pleasant customers had, the greater their buy intention was. Tsiotsou (2006) besides proved that perceived pleasant and buy intention have been immediately positively correlated, so perceived satisfaction ought to be used in predicting buy intention. The perceived degree of quality, which is a usual evaluative judgment of a product's gadgets and a key dimension in product preference and mindset closer to buying intention of that product (Doorn \& Verhoef, 2011) Perceived quality has an effective impact on client buy intention (Parasuraman et al., 1985, 1988). The superb effects closer to product quality originates from the perceived nice dominance (Zeithaml et al., 1996). Subsequently, perceived satisfaction considerably sustains a long-standing customer relationship such that buy intentions stay as the most fundamental influencer (Snoj et al., 2004). However, accessible empirical proof indicates that many instances are inconsistent. The research performed by Boulding et al. (1993) suggests that there is a widespread direct impact relationship between perceived quality and buy intention. Hendershot (2009) proposed that green products furnish excessive high-quality and excessive effectivity and provide customers greater benefits, such as being healthier. Simon (1992) proposed that the great of a green product is higher than others. Thus, shoppers will identify the pleasant positively if they experience a product that has green advertising characteristics.

\subsection{Environmental Consciousness (EC)}

Environmental consciousness is a notion reflecting a person's readiness to do anything to his/her very own environment. According to Lin, and Huang (2012), the system of growing environmental recognition requires time and an alternate in attitudes and buying habits; therefore, the relationship between environmental consciousness, mindset and buy intention must be monitored. Ariffin, Yusof, Putit, and Ariffin et. al, (2016) discovered an effective relationship between environmental attention and buy intention toward green products. Tsay (2009) discovered that the adoption of green consumption will assist enhance the environment great and are inclined to spend greater on green products. Many kinds of research have examined the effect of environmental focus on green product buy intention.

Environmental attention relates to a person's psychological elements to alternate the behavior to help and shield the surroundings (Zelezny and Schultz, 2000). Environmental aware buyers are these customers who are worried about the surroundings and exhibit some seasoned environmental behavior such as recycling, strength saving, and fending off plastic baggage (Schlegelmilch et al., 1996). Environmental focus which is a multidimensional assemble and represents an intellectual stage of a character, is affected with the aid of quite a number of antecedents such as psychographics, demographics, media, and political views. The variables which impact the seasoned environmental behavior are willingness to pay, involvement with the environment, comfort, and choice (Sharma and Bansal, 2013). H'Mida (2009) recommended that environmental awareness be influenced by using exterior elements such as media, household, tradition, and inner elements such as demographic, psychological, and monetary variables. Environmental aware customers are inclined extra closer to green merchandise and are prepared to pay a top green product rate. Environmental recognition is gorgeous for groups to produce the product that is beneficial to the herbal surroundings and has a much less unfavorable influence on the surroundings (Kang and James, 2007). Young customers who are 
extra environmentally mindful are inclined to spend extra on green products. Companies can make bigger environmental cognizance through giving rational and emotional messages. The green corporations can expand their market dimension and charge top rate via cautiously focused on the clients and designing the merchandise following their desires (Mina Okada and Mais, 2010).

\subsection{Environmental Knowledge (EK)}

According to Stutzman and Green (1982), environmental knowledge is necessary for developing a necessary mindset towards green consumption. Human beings who understand their surroundings can lead to environmental influence and the individual's environmental accountability, which can also contribute to sustainable improvement (Fryxell \& Lo, 2003). Noor et al. (2012) confirmed that environmental knowledge directly affects the environmental mindset in Malaysia. Furthermore, preceding researchers said that environmental expertise has a significant superb effect on consumers' environment (Barber et al., 2009). Knowledge is a key component in the consumer's choice to buy green merchandise (Maichum,2016). Wang, Liu, and Qi (2014) determined an excellent relationship between environmental information and buy intention toward green products. Moreover, Vicente-Molina, et. al, (2013) stated that environmental expertise has direct results on pro-environmental intention and conduct of college students.

\subsection{Green advertising (GA)}

According to Chan (2004), green advertisement is an announcement of green products' quality and production process, which contribute largely to environmental protection, safety, reduction from environmental pollution, and numerous positive impacts on the environment. According to Hartmann and Apaolaza-Ibanez (2009), green advertisement attempts to address several key issues such as environmentally friendliness of the products, environmental issues, value of corporate operations, promotion for environmental responsibilities, etc. During the promotion of green products, customers are influenced and make a purchase of green products by seeing the environmental cautiousness on labeling or packaging of green products. As an estimate demonstrated, most American green product purchasers buy a green product with environmental safety indication on packaging or products' labeling biodegradable (Ginsberg and Bloom, 2004). Green product and promotion had a positive and significant effect on Bangladeshi consumers' purchase behavior and reference groups also impact on products consciousness (Hossain, A. \& Khan, M. Y. H., 2018; Siddique, M. Z. R. \& Hossain, A., 2018). The business green advertisement may have the core three dimensions. Firstly, it seeks customers' attention that business organizations are conscious enough regarding the environmental issues. Secondly, it elaborates that the business organization takes the actions to improve the environment and protect the environment being polluted. Thirdly, it attempts to provide information regarding the business organizational activities taken to improve the environmental betterment and the positive consequences of these activities engaged by the organization (Davis, 1994). Chan (2004) established a mannequin that contained six proportions to measure the Chinese consumers' behavior toward the green advertisement, i.e., attitudes towards the advertisement, marketed product, intention to buy the marketed product, the application of the marketed product to the respondents' everyday lives, the utility of the advertisement in supervisory respondents to buy the product and perceived integrity of the advertising and marketing claim.

\subsection{Environmental Protection (EP)}

To Support environmental protection is one of the major motives for shoppers to behave environmentally pleasant during their buy choices (Gadenne et al., 2011). They seem for environmentally really useful characteristics associated with product graph and product utilization motive a minor effect on the surroundings and generate a significant distinction in environmental safety (Lee, 1990). People hunt for merchandise that is no longer detrimental to the creatures and countryside, their substances are recyclable and make minor environmental air pollution all through their usages. Thus, they understand the function of green products in enhancing the exceptional surroundings and show off aid for environmental safety by buying and proudly preserving green products (Escalas and Bettman, 2005). They are additionally capable to relate the relevance of greater expenses of green merchandise with environmental advantages supplied through them. This way, green merchandise adds importance to their environmentally pleasant way of life (Pickett-Baker and Ozaki, 2008) and increases 
effective tendency in the minds of consumers. Thus, customers pick green merchandise over non-green merchandise and translate their superb predisposition into the proper buy of environmentally-pleasant merchandise (Han et al., 2010). Supporting environmental safety refers to raise the mindset of surroundings' friendliness and attention for the sustainability of the herbal surroundings (Barr \& Gilg, 2006). Consumers who are worried about environmental protection consider the merchandise on the environmentally helping parameters (Lee, 1990). The desire for their buy is primarily based upon the environmental friendliness of products. They appear for the merchandise that is much less damaging for surroundings or has a full-size impact on surroundings (Escalas and Bettman, 2005). This issue of environmental safety stays existing in product from the utilization of uncooked fabric to the manufacturing of remaining correct (Jain and Kaur, 2004). Such customers check features of the product, recyclable ingredients, packaging, and others. For the enhancement of eco machine (Forkink 2010; Luchs et al. 2010). These shoppers examine the fees of merchandise with their eco-friendly features. The idea of deliberate conduct states that the beliefs of human beings make them exhibit specific behavior. Thus, customers who have a desire for green merchandise definitely buy an environmentally pleasant product.

\subsection{Environmental Responsibility (ER)}

Individuals' internal standpoints and private ideas that one can contribute to the safety of herbal resources, surroundings, and different species are pressure for environmental accountability (Gadenne et al., 2011). Consumers who experience themselves responsible regarding ecological worries undertake conduct of buying these merchandise that is now not damaging for residing matters (D'Souza et al. 2006). Many researchers have explored that inner dedication to surroundings enhances fine conduct closer to green purchases. They experience that their things to do can be delivered to their environment's safety (Lee, 2008, 2009). Their internal enthusiasm leads them in the direction of behaving environmentally pleasant to protect in opposition to risks confronted by way of the whole planet (Griskevicius et al., 2010). Many researchers have discovered how demographics affect the environmentally aware conduct of customers; however, it is now not evident how demographics are associated with drives that shape environmental duty in customers (D'Souza et al. 2007). In the past, researchers designed the research on environmental recognition and antecedents of environmental accountability; however they have the impact of drives that shape an individual's conduct has been unnoticed (Kilbourne and Pickett, 2008; Zuraidah et al., 2012). The beliefs, consideration, and environmental involvement of green customers make them undertake environmentally great activities. Environmentally accountable buyers are those who are inclined to aid and continue to be accountable for a higher sustainable future for the environment. The greater customers are inclined to buy green alternatives, the extra they are perceived to be environmentally accountable buyers and social actors (Nyborg et al., 2006). To intensify the grasp of surroundings accountability in Lebanon, it is necessary to supply residents with deep awareness, focus, and expertise regarding the country's environmental stipulations. Lee (2009) indicated that a feeling of accountability to shield the surroundings is normally vulnerable at the personal level. Individuals regularly blame environmental groups and governments for the absence of environmental protection. Moreover, studies inspecting the gender distinction with appreciation to environmental accountability point out that girls tend to be greater environmentally accountable than guys (Zelezny et al., 2000; Haytko and Matulich, 2008).

\subsection{Social Appeal (SA)}

According to Bearden and Rose (1990), the opinions, comments, \& perceptions of other individuals may influence customers' buying behaviors. Customers search and generate information regarding their targeted products and services at the time of interaction with other people who are already engaged in the purchase (Oliver and Lee, 2010). Customers gain, receive, and share information for a specific product as being a part of the social community (Dholakia et al., 2004). They attempt to judge and evaluate the product according to others' comments, opinions, and perceptions (Escalas and Bettman, 2005). Generally, customers determined the product quality, express their preferences and tastes by interacting with others (Dholakia et al., 2004). According to Lee (2008), customers developed their product choice and preferences by other peoples' perceptions where social appeal put a significant role and they are attracted \& influenced by those products which can create a sense of self for them (Kleine et al., 1993). Being a social animal, customers wish to purchase those products which are favorable to 
customers' social identity and social perception (Sen et al., 2001, Ozaki and Sevastyanova, 2011). Grier and Deshpande (2001) found that customers behave as environmentally friendly only when they are perceived as reputational for society and symbolic of the modern lifestyle. At the time of failure to behave like the other social perception, they are counted and perceived as outdated in society. It bears a representative sense in the society as eco-friendly, environmentally conscious, kindness and morality. It enriches consumers' social status and reputation as functional consequences such as trustworthiness and dedication to society (Griskevicius et al., 2010). Shifting in a person's views, moods, attitudes, or performances consequences from interplay with every other man or woman or a cluster (Ramayah, et al., 2010). According to Kalafatis et al.'s (1999) study, a social norm is whether or not a motion must or ought to be now not carried out by means of a respondent in a referent's factor of view. Referents ought to be friends, neighbors, no longer for income or for-profit organizations, teachers, parents, etc. Social impact is a proxy.

\subsection{Conceptual framework \& hypotheses development}

2.9.1 Conceptual framework

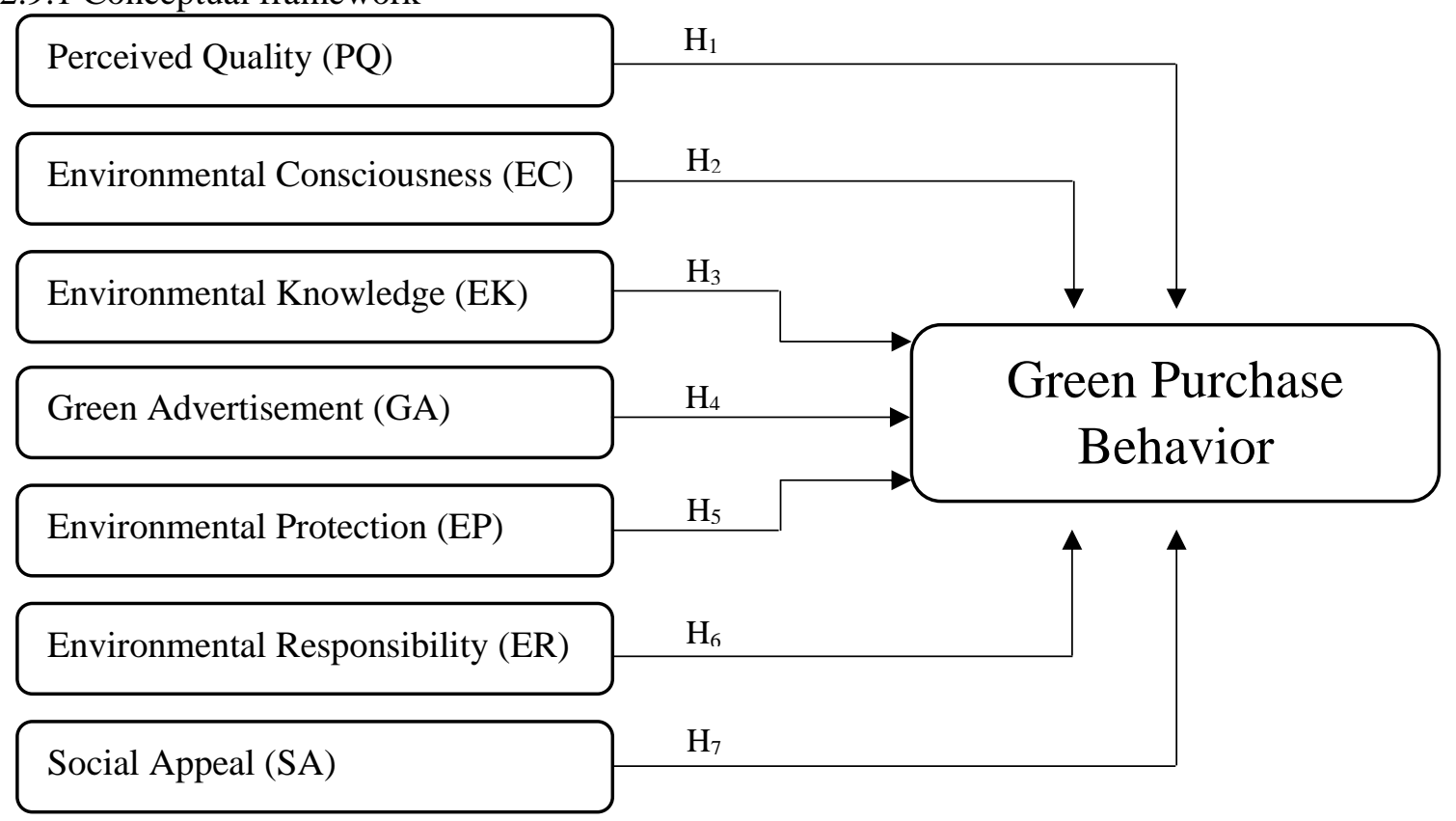

Figure 1. Research model

2.9.2 Hypotheses development

From the above studies, the research have been developed the following hypotheses.

$H_{l}$ Green Purchase Behavior and Perceived Quality of product are positively related to each other.

$\mathrm{H}_{2}$ : Green Purchase behavior and Environmental Consciousness are positively related to each other.

$\mathrm{H}_{3}$ Green Purchase behavior and Environmental Knowledge are positively related to each other.

$H_{4}$ : Green Purchase behavior and Green Advertising are positively related to each other.

$H_{5}$ : Green Purchase behavior and Environmental Protection are positively related to each other.

$H_{6}:$ Green Purchase behavior and Social Appeal are positively related to each other.

$H_{7}$ : Green Purchase behavior and Social Appeal are positively related to each other.

\section{Research methods}

\subsection{Types of research design}

This research investigated some factors regarding consumers' green purchase behavior. Firstly, Primary knowledge has been developed about consumers' green purchase behavior in the Bangladesh region by conducting exploratory research. After that, the descriptive research has been directed to attain the final output. 


\subsection{Information needs}

The study is enriched by the primary data as well as secondary data and the study is quantitative in nature. Basically, most of the data are obtained from the primary sources derived from the personal interview method online. The literature review has been generated by secondary sources, such as published materials, journals, books, internet sources, and others.

\subsection{Measurement instruments}

Using seven variables, the study stimulates consumers' green purchase actions in Bangladesh. The main methodology chosen for this study is the questionnaire survey method (online survey). The survey was conducted from September 2020 to December 2020. Primary data were gained through a structured survey questionnaire. Seven contracts are chosen to investigate the influence on consumers' green purchase behavior in Bangladesh.

\subsection{Scaling technique}

This study used a seven-point Likert scale to influence the respondents to ensure their participation by marking their responses as agreement or disagreement. Respondents are allowed to mark their judgment based on strongly disagree to agree for each research question strongly. Thirty respondents have done an antecedent test to finalize the questionnaire and ensuring the appropriateness of the questionnaire.

\subsection{Questionnaire design}

The questionnaire is divided into basic two parts. The first part is related to the respondent's demographic profile including gender, age, education, occupation, and income. The second part is comprised of 33 questions under the seven independent variables and five questions for the dependent variable. A close-ended questionnaire allows the researcher to easily analyze the questionnaire and permits to save both respondents and researcher's time. It facilitates the researcher to compare with other answers easily and effectively. So, the study used closed-ended questions to analyze the data more easily and conveniently.

\subsection{Sampling method and sample size}

The non-probability sampling method facilitates the researcher by saving them time and expenses of the researcher. Among the non-probability sampling methods, the study used convenience and a judgmental sampling technique. As a convenience and judgmental sampling technique, collect data conveniently which are researchers at hand and readily available. The sample size of the study is 324 .

\subsection{Data analysis}

Data are analyzed by using a statistical package for social science (SPSS) 25.0. SPSS has performed statistical equipment such as descriptive analysis, frequency \& percentage analysis, reliability test, and regression analysis to elaborate the primary data in an understandable format. The reliability test result for 38 items is 0.948 , which proved that all the hypotheses are much reliable and free from random error.

\section{Findings and discussions}

\subsection{Demographic profile of the respondents}

Table 1 shows the demographic profile of the respondents. It reveals that most of the respondents are male (59\%) and 191 in number. On the other hand, Female respondents are about $41 \%$ and 133 in number out of 324 respondents. Most of the respondents of this study are in the age group between 19 to 30 about $52.5 \%$ and 170 in number. $2^{\text {nd }}$ highest respondents are 31 to 40 years old about $24.4 \%$ and 79 in number. $3^{\text {rd }}$ highest are under 18 years old about $11.7 \%$ and 38 in number. $4^{\text {th }}$ highest are in the age group between 41 to 50 years old about $6.8 \%$ and 22 in number. Then the rest of the respondents are in the age group 51 to up about $4.6 \%$ and 15 in number. The table appears that the majority of the respondents' educational level is Graduation (49.7\%) 161 in number. $2^{\text {nd }}$ highest respondents' educational level is Post Graduation $(24.4 \%) 79$ in number. $3^{\text {rd }}$ highest respondents are undergraduates (23.5\%) 76 in number and the rest of the respondents are Ph.D. holders $(2.5 \%) 8$ in number. With regards to Monthly Income, most of the respondents' monthly income is less than 10000 BDT (43.5\%). $2^{\text {nd }}$ highest respondents' monthly income is nearly 10001 BDT to 25000 BDT (37.0\%). $3^{\text {rd }}$ highest 
respondents' monthly income is in $25001 \mathrm{BTD}$ to $40000 \mathrm{BTD}(12.0 \%) .4^{\text {th }}$ highest respondents' monthly income is in 40001 BDT to 55000 BDT $(4.0 \%) .5^{\text {th }}$ highest respondents' monthly income is more than 55000 BDT $(3.4 \%)$. By profession, the majority of the respondents are students $(47.2 \%) .2^{\text {nd }}$ highest respondents are Service Holder (21.6\%). ${ }^{\text {rd }}$ highest respondents are Self-Employment $(15.7 \%)$ and finally, the $5^{\text {th }}$ highest are Unemployed (15.4\%).

Table 1. Demographic profile of the respondents

\begin{tabular}{|c|c|c|c|}
\hline Demographic Variables & Items & Frequency & Percent \\
\hline \multirow{3}{*}{ Gender } & Male & 191 & 59.0 \\
\hline & Female & 133 & 41.0 \\
\hline & Total & 324 & 100.0 \\
\hline \multirow{6}{*}{ Age } & Under 18 & 38 & 11.7 \\
\hline & 19 to 30 & 170 & 52.5 \\
\hline & 31 to 40 & 79 & 24.4 \\
\hline & 41 to 50 & 22 & 6.8 \\
\hline & 51 to up & 15 & 4.6 \\
\hline & Total & 324 & 100.0 \\
\hline \multirow{5}{*}{ Education } & Under Graduate & 76 & 23.5 \\
\hline & Graduate & 161 & 49.7 \\
\hline & Post Graduate & 79 & 24.4 \\
\hline & $\mathrm{PhD}$ & 8 & 2.5 \\
\hline & Total & 324 & 100.0 \\
\hline \multirow{6}{*}{ Monthly Income } & Less than 10000 BTK & 141 & 43.5 \\
\hline & 10001 to $25000 \mathrm{BTK}$ & 120 & 37.0 \\
\hline & 25001 to $40000 \mathrm{BTK}$ & 39 & 12.0 \\
\hline & 40001 to $55000 \mathrm{BTK}$ & 13 & 4.0 \\
\hline & 55001 BTK to up & 11 & 3.4 \\
\hline & Total & 324 & 100.0 \\
\hline \multirow{5}{*}{ Occupation } & Unemployed & 50 & 15.4 \\
\hline & Student & 153 & 47.2 \\
\hline & Service Holder & 70 & 21.6 \\
\hline & Self-Employment & 51 & 15.7 \\
\hline & Total & 324 & 100.0 \\
\hline
\end{tabular}

\subsection{Descriptive statistics}

Table 2 indicates that the overall scenario of the factors that influence Consumers' green purchase intention. According to the table's mean value, most of the respondents are agreed upon Environmental consciousness and become the most significant factor of this study $(\mathrm{M}=5.7377$ and $\mathrm{SD}=1.27926)$. The next important factor of the study is Environmental responsibility $(M=5.7248$ and $\mathrm{SD}=1.0341)$. Then, the $3^{\text {rd }}$ vital factor is Environmental knowledge $(\mathrm{M}=5.6636$ and $\mathrm{SD}=1.2528)$. The $4^{\text {th }}$ important factor is Product quality $(\mathrm{M}=5.6605$ and $\mathrm{SD}=1.30511)$. The $5^{\text {th }}$ major factor is Environmental Protection $(\mathrm{M}=5.6543$ and $\mathrm{SD}=1.2135)$. The $6^{\text {th }}$ important factor is Social appeal $(\mathrm{M}=5.6096$ and $\mathrm{SD}=1.1789)$ and the least significant factor is Green advertisement $(\mathrm{M}=5.7248$ and $\mathrm{SD}=1.0341)$ of the study of consumers' green buying behavior. Besides, having a mean value of $5.6790 \& \mathrm{SD}=1.1599$ of green purchase behavior, the consumers are preferred green products over non-green products and have a positive \& significant influence on the buying of green products.

Table 2. Descriptive statistics

\begin{tabular}{|l|c|c|c|c|c|}
\hline Aspects & N & Min & Max & Mean & SD \\
\hline Product Quality (PQ) & & & & & \\
\hline 1. Meet the environmental requirements & 324 & 1.00 & 7.00 & 5.5772 & 1.39778 \\
\hline 2. Consume the least number of resources & 324 & 1.00 & 7.00 & 5.7006 & 1.20879 \\
\hline 3. Easy to recycle, disassemble and reuse & 324 & 1.00 & 7.00 & 5.8704 & 1.25478 \\
\hline
\end{tabular}




\begin{tabular}{|c|c|c|c|c|c|}
\hline 4. The superior quality & 324 & 1.00 & 7.00 & 5.6235 & 1.35845 \\
\hline 5. Environmental regulations & 324 & 1.00 & 7.00 & 5.5309 & 1.30573 \\
\hline Average & & & & 5.6605 & 1.30511 \\
\hline \multicolumn{6}{|l|}{ Environmental Consciousness (EC) } \\
\hline 6. Conscious of the environmental issues & 324 & 1.00 & 7.00 & 5.7315 & 1.24373 \\
\hline 7. Raise environmental consciousness & 324 & 1.00 & 7.00 & 5.7160 & 1.43581 \\
\hline 8. Green products contribute to sustainability & 324 & 1.00 & 7.00 & 5.8210 & 1.15865 \\
\hline 9. Environmental affect & 324 & 1.00 & 7.00 & 5.6821 & 1.27885 \\
\hline Average & & & & 5.7377 & 1.27926 \\
\hline \multicolumn{6}{|l|}{ Environmental Knowledge (EK) } \\
\hline 10. Knowledgeable about environmental issues & 324 & 2.00 & 7.00 & 5.6327 & 1.33689 \\
\hline 11. Environmental phrases and symbols & 324 & 1.00 & 7.00 & 5.5379 & 1.22986 \\
\hline 12. Environmentally safe & 324 & 1.00 & 7.00 & 5.7222 & 1.16847 \\
\hline 13. Manufacturing process & 324 & 1.00 & 7.00 & 5.6914 & 1.19226 \\
\hline 14. Packaging & 324 & 1.00 & 7.00 & 5.7346 & 1.33675 \\
\hline Average & & & & 5.6636 & 1.25285 \\
\hline \multicolumn{6}{|l|}{ Green Advertising (GA) } \\
\hline 15. Stand for their promises & 324 & 1.00 & 7.00 & 5.8148 & 1.44549 \\
\hline 16. Advertisements are believable & 324 & 1.00 & 7.00 & 5.3333 & 1.22411 \\
\hline 17. Experiences with the green brand & 324 & 1.00 & 7.00 & 5.4444 & 1.22411 \\
\hline 18. Trust in the green brand's name & 324 & 2.00 & 7.00 & 5.5926 & 1.07061 \\
\hline 19. Advertisements for green products & 324 & 2.00 & 7.00 & 5.5432 & 1.22714 \\
\hline Average & & & & 5.5457 & 1.23829 \\
\hline \multicolumn{6}{|l|}{ Environmental Protection (EP) } \\
\hline 20. Supporting environmental protection & 324 & 2.00 & 7.00 & 5.7778 & 1.13759 \\
\hline 21. Produces the least amount of pollution & 324 & 1.00 & 7.00 & 5.4722 & 1.28669 \\
\hline 22. Environment protection & 324 & 1.00 & 7.00 & 5.6512 & 1.27076 \\
\hline 23. Environmentally irresponsible & 324 & 1.00 & 7.00 & 5.7161 & 1.15917 \\
\hline Average & & & & 5.6543 & 1.21351 \\
\hline \multicolumn{6}{|l|}{ Social Appeal (SP) } \\
\hline 24. Perceived by others & 324 & 1.00 & 7.00 & 5.5216 & 1.29161 \\
\hline 25. Socially attractive & 324 & 2.00 & 7.00 & 5.6389 & 1.05095 \\
\hline 26. Relevant to lifestyle & 324 & 3.00 & 7.00 & 5.6358 & 1.08896 \\
\hline 27. Demand of time & 324 & 2.00 & 7.00 & 5.6423 & 1.28394 \\
\hline Average & & & & 5.6096 & 1.17887 \\
\hline \multicolumn{6}{|l|}{ Environmental Responsibility (ER) } \\
\hline 28. Responsible & 324 & 1.00 & 7.00 & 5.6790 & 1.13298 \\
\hline 29. Environmental protection issues & 324 & 2.00 & 7.00 & 5.9660 & 1.16266 \\
\hline 30. Environmentally responsible person & 324 & 2.00 & 7.00 & 5.6265 & 1.06130 \\
\hline 31. Effects of the environment & 324 & 2.00 & 7.00 & 5.5926 & 1.09632 \\
\hline 32. Responsibilities towards the environment & 324 & 2.00 & 7.00 & 5.8086 & 1.05299 \\
\hline 33. Not harmful to the environment & 324 & 2.00 & 7.00 & 5.6759 & 1.11418 \\
\hline Average & & & & 5.7247 & 1.10341 \\
\hline \multicolumn{6}{|l|}{ Purchase Behavior (PB) } \\
\hline 34. Environmentally-friendly & 324 & 2.00 & 7.00 & 5.9414 & 0.95387 \\
\hline 35. Expensive green products & 324 & 1.00 & 7.00 & 5.5741 & 1.27275 \\
\hline 36. Positive environmental contribution & 324 & 1.00 & 7.00 & 5.6327 & 1.25075 \\
\hline 37. Similar product quality & 324 & 1.00 & 7.00 & 5.4630 & 1.33835 \\
\hline 38. Manufactured from recycled materials & 324 & 2.00 & 7.00 & 5.7840 & 0.98426 \\
\hline Average & & & & 5.6790 & 1.15999 \\
\hline
\end{tabular}




\subsection{Reliability of statistics analysis}

Table 3 expressed the seven variables' internal reliability and steadiness (environmental responsibility, green advertising, environmental consciousness, environmental protection, perceived quality, social appeal, and environmental knowledge). According to Hair et al., (2010), All the variables have found no consistency error if the Cronbach's alpha value is up to the standard of 70\% (0.70). Here, the lowest Cronbach's alpha value is 0.713 (71.3\%) for the environmental consciousness factor. As a result, it's proved that the survey instruments are steady enough and avoided random error putting the Cronbach's alpha value exceeded 0.70 for all the variables.

Table 3. Reliability of statistics analysis

\begin{tabular}{|l|c|c|}
\hline \multicolumn{1}{|c|}{ Aspects } & Number of items & Cronbach's alpha \\
\hline Product Quality & 5 & 0.785 \\
\hline Environmental Consciousness & 4 & 0.713 \\
\hline Environmental Knowledge & 5 & 0.736 \\
\hline Green Advertisement & 5 & 0.766 \\
\hline Environmental Protection & 4 & 0.768 \\
\hline Social Appeal & 4 & 0.754 \\
\hline Environmental Responsibility & 6 & 0.740 \\
\hline
\end{tabular}

\subsection{Model summary}

Table 4, revealed that the worth of the correlation coefficient, $\mathrm{R}=.837(83.7 \%)$, recommends that there is a substantial positive correlation between consumers' green buying behavior \& environmental responsibility, green advertising, environmental consciousness, environmental protection, perceived quality, social appeal, environmental knowledge. However, only $70 \%$ (R-square values of 0.70 ) dissimilarity in consumers' green purchase behavior and environmental responsibility, green advertising, environmental consciousness, environmental protection, perceived quality, social appeal, environmental knowledge. Here, the adjusted R square is only .694, which means some other factors might influence consumers' green purchase behavior which are avoided from this study.

Table 4. Model summary

\begin{tabular}{|c|c|c|c|c|}
\hline Model & $\mathrm{R}$ & $\mathrm{R}$ Square & Adjusted R Square & Std. Error of the Estimate \\
\hline 1 & $.837^{\mathrm{a}}$ & .700 & .694 & .44358 \\
\hline
\end{tabular}

\subsection{ANOVA}

Table 5 elaborated the regression analysis that is accomplished by the study of linking consumers' green purchasing behavior along with environmental responsibility, green advertising, environmental consciousness, environmental protection, perceived quality, social appeal, environmental knowledge. Seven variables are suggested, and consequences are computed in Table 4 . It explained, $F$ value is 105.563 and sig value is 0.000 (sig. $\mathrm{f}<0.01$ ). Having 7 and 316 degrees of freedom the study proved the fitness for the model.

Table 5. ANOVA

\begin{tabular}{|l|l|c|c|c|c|c|}
\hline \multicolumn{2}{|c|}{ Model } & Sum of Squares & df & Mean Square & F & Sig. \\
\hline \multirow{3}{*}{1} & Regression & 145.399 & 7 & 20.771 & 105.563 & $.000^{\mathrm{b}}$ \\
\cline { 2 - 8 } & Residual & 62.178 & 316 & 0.197 & & \\
\cline { 2 - 8 } & Total & 207.577 & 323 & & & \\
\hline
\end{tabular}

\subsection{Coefficients}

The results of multiple regression analysis as demonstrates in Table 6, all aspects except perceived quality, and environmental consciousness affecting consumers purchase behavior of green products ( $\beta$ $=0.720,0.570,0.748,0.700, \& 0.670 ; \mathrm{t}$-value $=3.166,2.277,6.511,1.994, \& 3.842 ; \mathrm{p}<0.05) . \mathrm{H}_{3}, \mathrm{H}_{4}$, $\mathrm{H}_{5}, \mathrm{H}_{6}$, and $\mathrm{H}_{7}$, are accepted. Therefore, environmental knowledge, green advertising, environmental 
protection, social appeal, and environmental responsibility are significantly affected consumers purchase behavior of green products in Bangladesh.

Table 6. Regression analysis

\begin{tabular}{|l|c|c|c|c|}
\hline Aspects & Coefficients $(\beta)$ & T-value & P-value & Results \\
\hline Perceived Quality & 0.674 & 1.543 & .092 & Rejected \\
\hline Environmental Consciousness & 0.641 & 1.110 & 1.00 & Rejected \\
\hline Environmental Knowledge & 0.720 & 3.166 & .002 & Accepted \\
\hline Green Advertising & 0.570 & 2.277 & .023 & Accepted \\
\hline Environmental Protection & 0.748 & 6.511 & .000 & Accepted \\
\hline Social Appeal & 0.700 & 1.994 & .000 & Accepted \\
\hline Environmental Responsibility & 0.670 & 3.842 & .000 & Accepted \\
\hline
\end{tabular}

\section{Conclusion \& Implications}

The study's focal point is identifying the factors that have positive and significant influences on the consumers' green buying behavior in Bangladesh. Seven aspects (environmental responsibility, green advertising, environmental consciousness, environmental protection, perceived quality, social appeal, and environmental knowledge) are measured in this study and found the variables are significant with Consumers' green purchase behavior in Bangladesh. According to descriptive and regression analyses, Environmental consciousness is the most influential factor in consumers' green purchase behavior in Bangladesh. Other independent variables like environmental responsibility, environmental knowledge, product quality, environmental protection, social appeal, green advertisement have the influences. The study's results and analyses will help the researchers gain insight into green buying behavior in Bangladesh and direct them to determine other significant factors related to Consumers' green purchase behavior. This study may also help the government and other concerned regulatory authorities in their policymaking regarding the environmental \& consumption issues. Marketers and business people may be beneficial by developing $\&$ implementing their strategies regarding the Consumers' green purchase behavior.

\section{Limitation \& further direction}

The research is conducted in Bangladesh only, so the study result may not be applicable in any other country. The study's sample size is 324 only, which is not actually representative of all customers in Bangladesh. The study found several significant independent variables. Further research may be conducted by extending independent variables \& Sample size because there may be other independent variables that might influence consumers' green buying behavior.

\section{References}

Albayrak, T., Aksoy, S. and Caber, M. (2013). The effect of environmental concern and scepticism on green purchase behaviour. Marketing Intelligence and Planning, 31(1), 27-39.

Aman, A. L., Harun, A. and Hussein, Z. (2012). The influence of environmental knowledge and concern on green purchase intention the role of attitude as a mediating variable. British Journal of Arts and Social Sciences, 7(2), 145-167.

Ariffin, S., J. M. Yusof, L. Putit, and M. I. A. Shah (2016). Factors influencing perceived quality and repurchase intention towards green products. Procedia Economics and Finance, 37, 391-396.

Barber, N., Kuo, P. F., Bishop, M., \& Goodman, R. (2012). Measuring psychographics to assess purchase intention and willingness to pay. Journal of Consumer Marketing, 29(4), 280 - 292.

Barber, N., Taylor, C., and Strick, S. (2009). Wine consumers' environmental knowledge and attitudes: Influence on willingness to purchase. International Journal of Wine Research, 1(1), 59-72.

Barr, S. and Gilg, A. (2006). Sustainable lifestyles: framing environmental action in and around the home. Geoforum, 37, 906-920.

Bearden, W.O. and Rose, R.L. (1990). Attention to social comparison information: an individual difference factor affecting consumer conformity, Journal of Consumer Research, 16(4), 461-471.

Bohlen, G., Schlegelmilch, B.B. and Diamantopoulos, A. (1993). Measuring ecological concern: a multi-construct perspective. Journal of Marketing Management, 9(4), 415-430. 
Boulding, W., Kalra, A., Staelin, R. and Zeithaml, V.A. (1993). A dynamic process model of service quality: from expectations to behavioral intentions. Journal of Marketing Research, 30(1), 7.

Chan, R. Y. K. (2001). Determinants of Chinese consumers' green purchasing behaviour. Psychology and Marketing, 18(4), 389-413. http://dx.doi.org/10.1002/mar.1013

Chan, R.Y.K. (2004). Consumer responses to environmental advertising in China. Marketing Intelligence \& Planning, 22(4): 427-437. DOI: 10.1108/02634500410542789.

Chaudhuri, A., (2002). How brand reputation affects the advertising-brand equity link. Journal of Advertising Research, 42(3), 33-43.

Chen, T. B., \& Chai, L. T. (2010). Attitude towards the environment and green products: consumers' perspective. Management Science and Engineering, 4 (2), 27 - 39.

Davis, J.J. (1994). Consumer response to corporate environmental advertising. Journal of Consumer Marketing, 11(2), 25-37. DOI: 10.1108/07363769410058902.

Dholakia, U.M., Bagozzi, R.P. and Pearo, L.K. (2004). A social influence model of consumer participation in network- and small-group-based virtual communities, International Journal of Research in Marketing, 21(3), 241-263.

D'Souza (2006). Green Products and Corporate Strategy: An Empirical Investigation. Society and Business Review 1(2), 144-157.2007.

Escalas, J.E. and Bettman, J.R. (2005). Self-construal, reference groups and brand meaning. Journal of Consumer Research, 32(3), 378-389.

Forkink, A. (2010). Perception, awareness, and acceptance of green kitchen cleaners: go green market research. Online report. Retrieved 24 June 2012, http://www.greenbook.org/Content/GoGreen/Green_Cleaners_report.pdf.

Fryxell, G. E., and. Lo, C. W., (2003). The influence of environmental knowledge and values on managerial behaviours on behalf of the environment: an empirical examination of managers in China. Journal of Business Ethics, 46(1), 45-69.

Gadenne, D., Sharma, B., Kerr, D. and Smith, T. (2011). The influence of consumers' environmental beliefs and attitudes on energy saving behaviour. Energy Policy, 39(12), 7684-7694.

Ginsberg, J. M and Bloom P.N. (2004). Choosing the Right Green Marketing Strategy, Massachusetts Institute of Technology (MIT). Sloan management Review, 79- 84

Grier, S.A. and Deshpande, R. (2001). Social dimensions of consumer distinctiveness: the influence of social status on group identity and advertising persuasion, Journal of Marketing Research, 38(2), 216-224.

Griskevicius, V., Tybur, J.M. and Bergh, B.V. (2010). Going green to be seen: status, reputation, and conspicuous conservation, Journal of Personality and Social Psychology, 98(3), 392-404.

H'Mida, S. (2009). Factors contributing in the formation of consumers' environmental consciousness and shaping green purchasing decisions. Computers \& Industrial Engineering, CIE 2009: International Conference, IEEE, pp.957-962.

Han, H., Hsu, L. and Sheu, C. (2010). Application of the theory of planned behaviour to green hotel choice: testing the effect of environmental friendly activities. Tourism Management, 31(3), 325334.

Hair, J.F., Black, W.C., Babin, B.J., \& Anderson, R.E. (2010). Multivariate Data analysis. Seventh edition. Prentice Hall, Upper Saddle River, New Jersey.

Hartmann, P. \& Apaolaza Ibañez, V. (2006). Green value added. Marketing Intelligence and Planning, 24(7), 673-680.

Haytko D, Matulich E. (2008). Green advertising and environmentally responsible consumer behaviour: linkages examined. Journal of Management and Marketing Research, 7(1), 2-11.

Hendershot, S. (2009). Is green enough to lure clients? Crain's Chicago Business, 32(28), 16.

Hossain, A., \& Khan, M. Y. H. (2018). Green marketing mix effect on consumers buying decisions in Bangladesh. Marketing and Management of Innovations, 10(4), 298- 306. https://www.feedough.com/greenproduct/\#: :text=A\%20green\%20product\%20is\%20a, waste\% 20 and $\% 20$ maximizing\%20resource\%20efficiency.

Jain, Sanjay \& Kaur, Gurmeet. (2004). Green Marketing: An Attitudinal and Behavioural Analysis of Indian Consumers. Global Business Review - Global Bus Rev. 5, 187-205. $10.1177 / 097215090400500203$. 
Kalafatis, S. P., Pollard, M., East, R. \& Tsogas, M. H. (1999). Green marketing and Ajzen's theory of planned behavior: a cross-market examination. Journal of Consumer Marketing, 16, 441-460

Kang, G.D. and James, J. (2007). Revisiting the concept of a societal orientation: conceptualization and delineation. Journal of Business Ethics, 73(3), 301-318.

Kawitkar, S. S. (2013). Impact of eco-friendly products on consumer behavior. International Indexed \& Refereed Research Journal, 40, 42 - 44.

Kilbourne, W. and Pickett, G. (2008). How materialism affects environmental beliefs, concern, and environmentally responsible behaviour, Journal of Business Research, 61(9), 885-893.

Kleine, R.E. III, Kleine, S.S. and Kernan, J.B. (1993). Mundane consumption and the self: a socialidentity perspective. Journal of Consumer Psychology, 2(3), 209-235.

Lee K. (2009). Gender differences in Hong Kong adolescent consumers' green purchasing behaviour. Journal of Consumer Marketing, 26(2), 87-96.

Lee, D.H. (1990). Symbolic interactionism: some implications for consumer self-concept and product symbolism research. Advances in Consumer Research, 17(1), 386-392.

Lee, K. (2008). Opportunities for Green Marketing: Young Consumers. Marketing Intelligence and Planning, 26(6), 573-586. http://dx.doi.org/10.1108/02634500810902839.

Lee, K. (2009). Gender differences in Hong Kong adolescent consumers' green purchasing behaviour, Journal of Consumer Marketing, 26(2), 87-96.

Lin, P.-C, and Y.-H. Huang (2012). The influence factors on choice behavior regarding green products based on the theory of consumption values. Journal of Cleaner Production, 22(1), 11-18.

Luchs, M. G. et al. (2010). The sustainability liability: potential negative effects of ethicality on product preference. Journal of Marketing, 74, 18-31.

Maichum, K., Parichatnon, S. and. Peng, K.-C (2016). Application of the extended theory of planned behavior model to investigate purchase intention of green products among Thai consumers. Sustainability, 8(10), 1077.

Mina Okada, E. and Mais, E.L. (2010). Framing the 'Green' alternative for environmentally conscious consumers. Sustainability Accounting, Management and Policy Journal, 1(2), 222-234.

Noor, N. A., \& Muhammad, A. (2012). Emerging green product buyers in Malaysia: Their profiles and behaviors. Clute Institute International Conference, June, 2012, Rome, Italy.

Noor, N., Muhammad, A., Kassim, A., C. Jamil, N. Mat, N. Mat, and H. Salleh, (2012). Creating green consumers: how environmental knowledge and environmental attitude lead to green purchase behaviour? International Journal of Arts and Sciences, 5(1), 55-71.

Nyborg K, Howarth R, Brekke K. (2006). Green consumers and public policy: on socially contingent moral motivation. Resource and Energy Economics, 28(4), 351-366.

Oliver, J.D. and Lee, S. (2010). Hybrid car purchase intentions: a cross-cultural analysis, Journal of Consumer Marketing, 27(2), 96-103.

Ozaki, R. and Sevastyanova, K. (2011). Going hybrid: an analysis of consumer purchase motivations, Energy Policy, 39(5), 2217-2227.

Paetz A, Dutschke E, Fichtner W. (2012). Smart homes as a means to sustainable energy consumption: a study of consumer perceptions. Journal of Consumer Policy, 35(1), 23-41.

Parasuraman, A., Zeithaml, V.A. and Berry, L.L. (1985). A conceptual model of service quality and its implications for future research. The Journal of Marketing, 49(4), 41-50.

Parasuraman, A., Zeithaml, V.A. and Berry, L.L. (1988). Servqual: a multiple-item scale for measuring consumer perc. Journal of Retailing, 64(1), 12.

Petrick, J. F., (2002). Development of multi-dimensional scale for measuring the perceived value of a service. Journal of Leisure Research, 34(2), 119-134.

Pickett-Baker, J. and Ozaki, R. (2008). Pro-environmental products: marketing influence on consumer purchase decision. Journal of Consumer Marketing, 25(5), 281-293.

Ramayah, T., Lee, J. W. C. \& Mohamad, O. (2010). Green product purchase intention: some insights from a developing country. Resources, Conservation and Recycling, 54, 1419-1427.

Rashid, N. R. N. A. (2009). Awareness of eco-label in Malaysia green marketing initiative. International Journal of Business and Management, 4(8), 132-141. http://dx.doi.org/10.5539/ijbm.v4n8p132 
Schlegelmilch, B.B., Bohlen, G.M. and Diamantopoulos, A. (1996). The link between green purchasing decisions and measures of environmental consciousness. European Journal of Marketing, 30(5), $35-55$.

Sen, S., Zeynep, G.-C. and Vicki, M. (2001). Withholding consumption: a social dilemma perspective on consumer boycotts, Journal of Consumer Research, 28(3), 399-417.

Sharma, K. and Bansal, M. (2013). Environmental consciousness, its antecedents and behavioural Outcomes. Journal of Indian Business Research, 5(3), 198-214.

Siddique M.Z.R. \& Hossain A. (2018). Sources of consumers' awareness toward green products and its impact on purchasing decision in Bangladesh. Journal of Sustainable Development, 11(3), 9-22.

Simon, F. L. (1992). Marketing green products in the triad. The Columbia Journal of World Business, 268-285.

Snoj, B., Korda, A.P. and Mumel, D. (2004). The relationships among perceived quality, perceived risk and perceived product value. Journal of Product and Brand Management, 13(3), 156-167.

Stutzman, T. M. and Green, S. B., (1982). Factors affecting energy consumption: two field tests of the Fishbein-Ajzen model. The Journal of Social Psychology, 117(2), 183-201

Sua, J. C. P., Wang, L., \& Ho J. C. (2012). The impacts of technology evolution on market structure for green products. Mathematical and Computer Modelling, 55, 1381-1400.

Tsay, Y. Y., (2009). The impacts of economic crisis on green consumption in Taiwan, in Proc. The Portland International Conference on Management of Engineering \& Technology, 2367-2374,

Tsiotsou, R., (2006). The role of perceived product quality and overall satisfaction on purchase intentions. International Journal of Consumer Studies, 30(2), 207-217.

Van Doorn, J., \& Verhoef, P. C. (2011). Willingness to pay for organic products: Differences between virtue and vice foods. International Journal of Research in Marketing, 28(3), 167-180.

Vermeir, I. and Verbeke, W. (2004). Sustainable food consumption: exploring the consumer 'attitudebehavioural intention' gap", Journal of Agricultural and Environmental Ethics, 19(2), 169-194.

Vicente-Molina, M. A. Fernández-Sáinz, A., and Izagirre-Olaizola, J. (2013). Environmental knowledge and other variables affecting pro-environmental behaviour: comparison of university students from emerging and advanced countries. Journal of Cleaner Production, 61, 130-138, 2013.

Wahid, N. A., Rahbar, E., \& Tan, S. S. (2011). Factors influencing the green purchase behavior of Penang environmental volunteer. International Business Management, 5 (1), 38 - 49.

Wang, P., Liu, Q., and Qi, Y. (2014). Factors influencing sustainable consumption behaviors: a survey of the rural residents in China. Journal of Cleaner Production, 63,152-165.

Zeithaml, V. A., (1988). Consumer Perceptions of Price, Quality, and Value: A Means-End Model and Synthesis of Evidence. Journal of Marketing, 52(3), 2-22.

Zeithaml, V.A., Berry, L.L. and Parasuraman, A. (1996). The behavioral consequences of service Quality. The Journal of Marketing, 60(2), 31-46.

Zelezny L, Chua P, Alrich C. (2000). Elaborating on gender differences in environmentalism. Journal of Social Issues, 56(3), 443-457.

Zelezny, L.C. and Schultz, P.W. (2000). Psychology of promoting environmentalism: promoting Environmentalism. Journal of Social Issues, 56(3), 365-371.

Zuraidah, R., Hashima, H.N., Yahya, K.W. and Mohamad, S.A. (2012). Environmental conscious behaviour among male and female Malaysian consumers, OIDA International Journal of Sustainable Development, 4(8), 55-64. 